\title{
ANALISIS SOSIAL EKONOMI MASYARAKAT DI ZONA REHABILITASI TAMAN NASIONAL MERU BETIRI, JEMBER, JAWA TIMUR \\ (Kasus di desa Andongrejo, Wonoasri, Curabnongko dan Sanenrejo) \\ Analisys Social Of Communities Economic \\ In Rebabilitation Zone National Park Meru Betiri, Jember, East Java \\ (Case in village side Andongrejo, Wonosari, Curabnongko and Sanenrejo)
}

Oleh:

\author{
Dra. Dewi Subaktini, M.Si. \\ (Sosiologi Sosial) \\ BP2TP DAS - IBB Surakarta
}

\begin{abstract}
ABSTRACK
$\mathrm{N}$ Part of South arch residing in region tip East Java Part of South arch. This National Park has various function in protecting system of the life of flora and fauna with the ecosystems. The existence of National Park has a big advantagerus for the communities who live around the area.

Along with change of period to governance in the new order becomes a reform governance makes the TN-MB ruined as the effect of foray. Hall Management of DAS Sampean-Madura (2002) reports that National Park of Meru Betiri which its width $58.000 \mathrm{Ha}$, for about $4.023 \mathrm{Ha}$ have destroyed without vegetation or it becomes farm of season crop. With that condition, so the area is specified as Rehabilitation zone

The research is conducted with the method of survey then clarified with the method of Participatory Rural Appraisal (PRA). Analyses data used by the descriptive analysis qualitative. The result of the research can be known that there is a high resistence or threat to the society who live around the TN MB which specified with the job where mostly as a farmer (35,86\%) and hard farmer (38,74\%) while the most agraris 16,6 person / Ha. Mine's land for about 0,219 $\mathrm{Ha} / \mathrm{KK}$ and productive age 63,8\%.

So, it can be conclude that the rehabilitation of TN $M B$ for this time is more concentrate to the zone area of rehabilitation and the edvantage of avoiding the farm to the jungle zone and conten zone. It is also necessary that the factor of social economic not only used to formulate the zonasi but it also used as a basis for a reconstruction of Merubetiri National Park.
\end{abstract}

Key Words : Social, Communities Economic and National Park

\section{PENDAHULUAN}

\section{Latar Belakang}

Pemanfaatan sumberdaya alam secara optimal dan rasional bertujuan untuk meningkatkan kesejahteraan masyarakat. Pemanfaatan sumberdaya alam secara bijaksana sesuai dengan kaidah kelestarian tidak saja akan meningkatkan kesejahteraan masyarakat tetapi juga akan mendapatkan manfaat yang berkesinambungan. Salah satu model pemanfaatan sumberdaya alam secara optimal. Penunjukan Taman Nasional berdasarkan Surat Keputusan Menteri Kehutanan No 277/Kpts-VI/1997, tanggal 23 Mei 1997 tentang Suaka Margasatwa Meru Betiri menjadi Taman Nasional Meru Betiri.

Taman Nasional Meru Betiri (TNMB) yang ditetapkan sejak tahun1997 memiliki 
potensi yang mampu menjalankan ketiga embanan (mission) juga merupakan ciri khas Taman Nasional terdiri dari :

1. Perlindungan sistem penyangga kehidupan,

2. Pengawetan keanekaragaman jenis tumbuhan dan satwa beserta ekosistemnya dan

3. Pemanfaatan secara lestari sumberdaya hayati dan ekosistemnya.

Nilai-nilai penting yang terkandung dalam Taman Nasional seperti perlindungan fungsi hidrologi, potensi keanekaragaman hayati dan potensi pariwisata alam, sangat besar manfaatnya bagi masyarakat sekitar daerah penyangga .Beberapa satwa yang dilindungi di Taman Nasional Meru Betiri seperti Harimau Jawa, Banteng dan Burung Rangkong, juga Bunga Raflesia yang sangat dikenal masyarakat luas tidak hanya di sekitar Taman Nasional saja. Bunga Raflesia sebagai salah satu bahan utama obat-obat tradisional yang diproduksi oleh sebagian besar masyarakat di sekitar Taman Nasional.

Keberadaan Taman Nasional sangat besar sekali manfaatnya bagi masyarakat desa sekitar kawasan. Banyak diantara mereka mengambil hasil hutan untuk memenuhi kebutuhan hidup sehari-hari dengan cara menjual hasil hutan bahkan ada sebagian penduduk yang menjadikan sebagai pekerjaan pokok.

Balai Pengelolaan DAS SampeanMadura (2002) melaporkan bahwa Taman Nasional Meru Betiri yang mempunyai luas $58.000 \mathrm{Ha}$, sekitar 4.023 Ha telah rusak tanpa vegetasi atau menjadi lahan usahatani tanaman semusim. Dengan kondisi di kawasan demikian, maka kawasan tersebut ditetapkan sebagai Zona Rehabilitasi.
Hubungan saling ketergantungan manusia dan hutan dalam suatu sistem interaksi kehidupan telah berlangsung lama (Rush, 2003). Masyarakat di dalam dan sekitar hutan banyak menggantungkan hidupnya pada keberadaan hutan (Departemen Kehutanan dan Perkebunan, 1998) dan memiliki hubungan erat dengan hutan (Mubyarto et al, 1992).

Menurut Alikodra (1976), perkembangan peradaban manusia dalam hubungannya dengan pemanfaatan sumberdaya alam, dapat dibagi menjadi empat tahab. Tahap pertama adalah masyarakat nomaden yang hidupnya berpindah pindah di hutan belantara, mereka berburu binatang, mengumpulkan bahan makanan dari tumbuhan dan bahan untuk menutup dan melindungi tubuhnya. Mereka mencoba menanam tumbuhan untuk bahan makanan dan obat-obatan serta memelihara anak binatang buruan di sekitar tempat tinggalnya sehingga berbagai jenis binatang dan tanaman dapat dibudidayakan. Mereka membangun tempat tinggal dan membudidayakan komoditi pertanian dan ternak pada lahan yang mereka kuasai. Tahap keempat adalah masyarakat industri yang mengexploitasi sumberdaya alam dengan menggunakakn berbagai peralatan modern. Tahap - tahap perkembangan masyarakat tersebut tentunya berpengaruh terhadap perkembangan kelembagaan di masyarakat.

Dalam hubungannya dengan pemanfaatan sumber daya alam, masyarakat dipengaruhi oleh kebutuhan intrinsik dan faktor lingkungan yang berpengaruh terhadap kelangsungan hidupnya. Beberapa ahli Antropologi, seperti Geertz, Berger, Meyer dan Zucker (Scott, 1995) menekankan unsur kognitif dalam kelembagaannya. Dalam perspektif kognitif, penduduk asli 
yang berada di dalam dan sekitar hutan menganggaphutan sebagai bagian dari hidupnya. Fenomina sosial ini tidak hanya terjadi di Indonesia tetapi juga terjadi pada suku - suku asli di beberapa benua seperti Aborigin di Australia dan Indian di Amerika (Goldsmith, 1995). Sedangkan Devung, 1996 mengatakan di Kalimantan Timur, hutan dan Taman Nasional dimanfaatkan sebagai sumber utama mata pencaharian masyarakat setempat dan sebagian besar pendapatan masyarakat juga masih tergantung dari hasil - hasil hutan.

\section{METODE PENELITIAN}

Lokasi penelitian dilakukan di Taman Nasional Meru Betiri (TN MB) Jember Jawa Timur. Secara administrasi kawasan TN MB sebagian berada di Wilayah Kabupaten Jember dan sebagian berada di Wilayah Banyuwangi. Untuk memberikan gambaran letak wilayah TN MB seperti peta pada Gambar 1.
Penelitian dilaksanakan pada bulan Desember 2003, tempat penelitian di kawasan Seksi Konservasi II Ambulu, tepatnya di Desa Andongrejo, Desa Curahnongko, Desa Sanenrejo dan Desa Wonoasri. Kecamatan Tempurejo. Keempat desa tersebut berbatasan langsung dengan kawasan penyangga Taman Nasional Meru Betiri (TNMB). Alasan memilih lokasi penelitian di Jember, ancaman / desakan penduduk di sekitar TNMB cukup tinggi dan sangat mengancam kelestarian TNMB.

Data primer diperoleh menggunakan metode wawancara dengan 60 responden yang terdiri dari kelompok tani, tokoh masyarakat, PKK Penggerak TOGA dan stakeholder yang terlibat dalam kawasan konservasi di daerah penyangga Taman Nasional Meru Betiri. Data sekunder diperoleh dari instansi terkait dengan penelitian.

Kajian dilakukan dengan metode survey dengan unit analisis rumah tangga

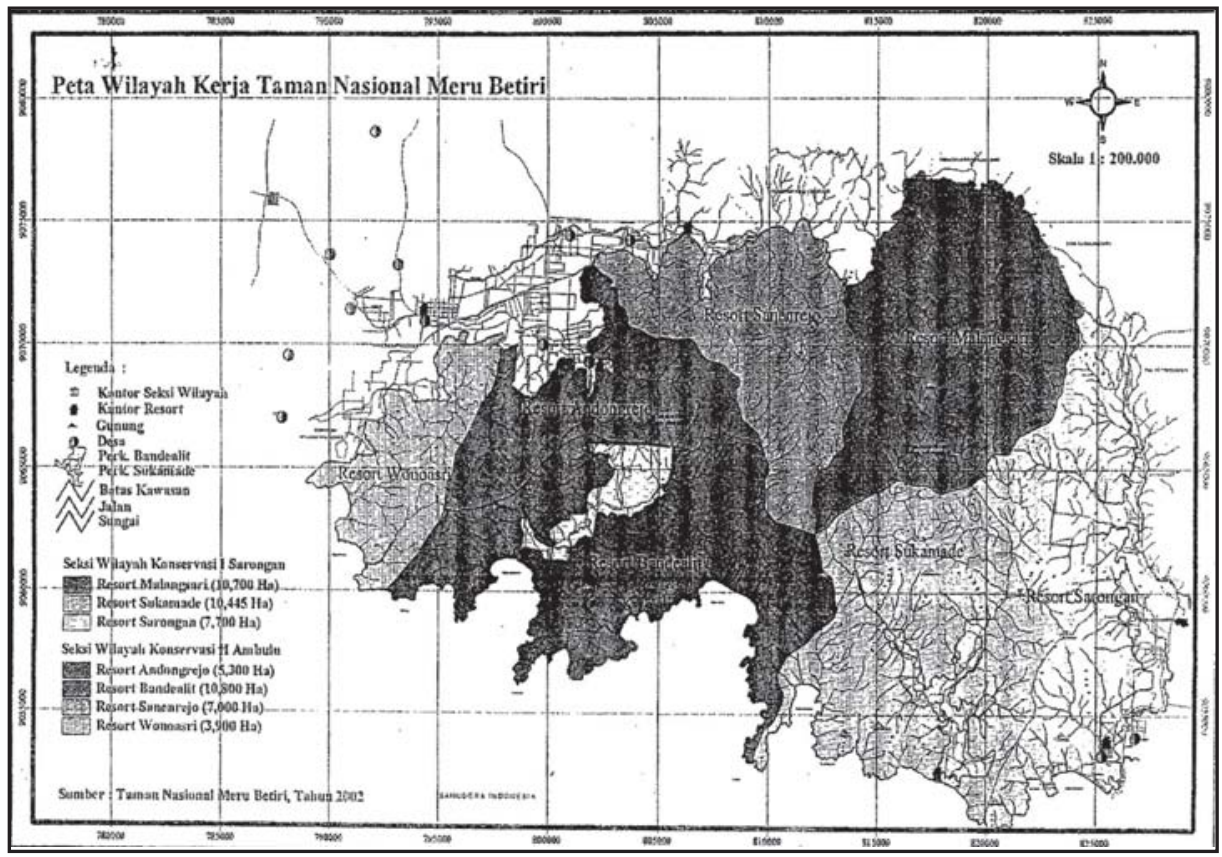

Gambar 1 : Peta Letak Wilayah Kerja - Taman Nasional Meru Betiri 
petani. Untuk mengetahui sikap masyarakat terhadap rehabilitasi Taman Nasional dengan cara Partisipatory Rural Appraisal (PRA). Analisa data dilakukan dengan diskriptif kualitatif.

\section{HASIL DAN PEMBAHASAN}

\section{Karakteristik Lokasi}

Secara geografis Taman Nasional Meru Betiri (TNMB) terletak antara $8^{0} 20^{\prime} 48^{\prime \prime}-8^{0} 33^{\prime} 48^{\prime \prime}$ LS dan $113^{\circ} 38^{\prime} 48^{\prime \prime}$ $113^{0} 58^{\prime} 30^{\prime \prime}$ Kawasan Taman Nasional Meru Betiri memiliki luas 58.000 Ha. Secara administratif pemerintahan TN-MB terletak didua wilayah Kabupaten yakni bagian barat termasuk Kabupaten Jember seluas $37,585 \mathrm{Ha}$ dan bagian Timur Kabupaten Banyuwangi seluas 20,415 Ha. Batas-batas wilayah TNMB adalah :

- Sebelah utara, berbatasan dengan sungai sanen dan perkebunan Malangsari

- Sebelah timur, perkebunan Sumberjambe dan perkebunan Treblasala

- Sebelah selatan, berbatasan dengan Samudra Indonesia dan

- Sebelah barat Desa Curahnongko, Desa Curahtakir dan perkebunan Kotablater.

Daerah pemukiman yang padat penduduknya seperti Desa Curahnongko, Desa Andongrejo, Desa Sanenrejo dan Desa Wonoasri, merupakan desa terdekat dengan kawasan penyangga Taman Nasional Meru Betiri. Keempat desa tersebut berada di Wilayah Kecamatan Tempurejo, jarak antara desa-desa ini $+500 \mathrm{~m}$ dari Taman nasional. Sedangkan luas masingmasing desa untuk lokasi kajian disajikan pada Tabel 1.

Kondisi geografis di lokasi kajian mempunyai topografi gelombang, berbukit dengan variasi dataran rendah pantai sampai pegunungan dengan ketinggian $1.223 \mathrm{~m} / \mathrm{dpl}$. Desa kajian beriklim C dan mempunyai curah hujan $2.300-4.000 \mathrm{~mm}$ pertahun. dengan rata-rata bulan kering 4 bulan dan bulan basah 7 bulan. Hasil survey John Seidenticker tahun 1976 dalam laporan BP DAS Sampean - Madura (2002).

\section{Lahan}

Karakteristik lahan di Taman Nasional Merubetiri dilakukan dengan membagi seluruh kawasan daratan dalam 84 satuan unit lahan. (Paimin dkk, 2003). Parameter penyusunan karakteristik lahan meliputi lereng, jenis tanah, \% batuan singkapan, kedalaman tanah dll. Luas lahan TN MB yang terdeliniasi dalam inventarisasi (tidak termasuk perkebunan Bandealit dan Sukamade) meliputi 54.828,83 Ha. Jenis tanah utamanya adalah entisol, Inseptisol dan Spodosol seperti dalam Table 2.

Tabel 1 . Luas Desa Di Lokasi Kajian

\begin{tabular}{|c|l|c|}
\hline $\begin{array}{c}\text { No } \\
\text { Number) }\end{array}$ & \multicolumn{1}{|c|}{$\begin{array}{c}\text { Desa } \\
\text { (Village) }\end{array}$} & $\begin{array}{c}\text { Luas Total }\left(\mathrm{Km}^{2}\right) \\
\text { (Total Wide) } \mathrm{Km}^{2}\end{array}$ \\
\hline 1 & Curahnongko & 283,39 \\
2 & Andongrejo & 262,79 \\
3 & Sanenrejo & 68,89 \\
4 & Wonoasri & 6,18 \\
\hline
\end{tabular}

Sumber data : Monografi Desa Kajian 2002 
Tabel 2 : Luas Masing - masing Jenis Tanah di Taman Nasional Merubetiri

\begin{tabular}{|c|c|c|}
\hline \multicolumn{2}{|c|}{ Jenis Tanah } & $\begin{array}{c}\text { Luas } \\
\mathbf{( H a} / \mathbf{\%})\end{array}$ \\
\hline Kode & Ordo & $47.271,57(86,2)$ \\
\hline $\mathbf{E}$ & Entisol & $6.264,3047(11,4)$ \\
\hline $\mathbf{I}$ & Inseptisol & $1.292,954(2,45)$ \\
\hline $\mathbf{S}$ & Spodosol & $54.828,83$ \\
\hline
\end{tabular}

Sebagian besar TN MB terdiri dari bentuk lahan Mountain (pegunungan), seluas 38.247,37 Ha dan Hilly (perbukitan), seluas 12.107,04 Ha yang utamanya berada zona inti dan zona rimba. Sedangkan pada zona rehabilitasi dan zona pemanfaatan intensif bentuk lahannya Alluvial, dataran dan sedikit karts. Sehingga untuk pemetaan zonasi TN MB sebagian besar sudah sesuai dengan bentuk lahan dimana sesuai dengan tingkat kesulitan jangkauan masyarakat terhadap zona rimba dan zona inti disamping juga kelerengansebagian besar 45\%. Peta Penggunaan Lahan Taman Nasional Meru Betiri terlihat dalam Gambar 2.

Penggunaan lahan di Zona Penyangga yang tidak mengikuti kaidah konservasi tanah menyebabkan lahan ini terlihat gundul (Gambar 1). Untuk mengatasi masalah tersebut di lokasi kajian telah dilakukan pemberdayaan masayarakat yang dilakukan oleh manajemen Taman Nasional, ornop LATIN (Bogor) dan ornop lokal Konservasi Alam Indonesia Lestari (KAIL) di Kecamatan Ambulu. Hal ini sesuai dengan pendapat Sudarmaji, 2001. Sebagai salah satu upaya untuk mengatasi hal tersebut, antara lain memberikan pelatihan pembudidayaan berbagai jenis tanaman dan satwa liar. Upaya kerjasama dalam kegiatan tersebut dapat mengajak masyarakat untuk ikut berpartisipasi aktif dalam melaksanakan konservasi sumberdaya alam hayati sekaligus mengajak masyarakat sekitar kawasan Taman Nasional membiasakan diri tidak mengambil hasil hutan secara langsung dari Taman Nasional Meru Betiri.

Tabel 3. Jenis, Luas dan Rata-Rata Kepemilikan Lahan di lokasi Penelitian

\begin{tabular}{|c|l|r|r|r|r|c|}
\hline $\begin{array}{c}\text { No } \\
\text { Number) }\end{array}$ & \multicolumn{1}{|c|}{$\begin{array}{c}\text { Nama } \\
(\text { Name })\end{array}$} & $\begin{array}{c}\text { Sawah } \\
\text { (Wet rice } \\
\text { field) } \\
(\mathrm{Ha})\end{array}$ & $\begin{array}{c}\text { Pekarangan } \\
\text { (Yard) } \\
(\mathrm{Ha})\end{array}$ & $\begin{array}{c}\text { Tegal } \\
(\text { Dry field }) \\
(\mathrm{Ha})\end{array}$ & $\begin{array}{c}\text { Jumlah } \\
\text { (Total) } \\
(\mathrm{Ha})\end{array}$ & $\begin{array}{c}\text { Rata-2 Kepemil } \\
\text { Lahan } \\
\text { The levels } \\
\text { ownership of farm } \\
\text { (Ha) }\end{array}$ \\
\hline 1 & Andongrejo & 60.27 & 53.03 & 42.08 & 155.38 & 0.11 \\
\hline 2 & Curahnongko & 60.00 & 153.42 & 88 & 301.42 & 0.15 \\
\hline 3 & Sanenrejo & 175.65 & 87.05 & 180.12 & 442.82 & 0.30 \\
\hline 4 & Wonoasri & 205.00 & 127.20 & 248.37 & 580.57 & 0.23 \\
\hline \multicolumn{2}{|l}{ Jumlah } & 500.92 & 420.70 & 558.57 & 1480.19 & 0.20 \\
\hline
\end{tabular}

Sumber data : Monografi Desa Andongrejo, Ds. Curahnongko, Ds. Sanenrejo

Dan Ds. Wonoasri. Tahun 2002 semester I 


\section{Jenis dan Luas Penggunaan Lahan}

Penggunaan lahan oleh masyarakat di tiga desa penelitian belum dilakukan secara optimal dalam arti bahwa pengolahan tanah khususnya lahan persawahan masih dilakukan secara tradisional dan sebagian besar belum mendapatkan irigasi teknis. Jenis, luas dan rata-rata kepemilikan lahan yang ada di lokasi penelitian disajikan pada Tabel 3.

Luas penguasaan lahan petani relatif sempit dan hal ini akan mempengaruhi tingkat pendapatan dan usahatani yang mereka lakukan, ini terlihat pada Tabel 2 bahwa kepemilikan rata-rata petani di kawasan penyangga Taman Nasional Meru Betiri seluas $0.20 \mathrm{ha} / \mathrm{kk}$. Masyarakat yang masih miskin lahan tetap akan menjadi ancaman bagi program rehabilitasi di kawasan penyangga. Pada dasarnya pemanfaatan lahan di kawasan Penyangga bertentangan dan melanggar hukum, namun desakan ekonomi masyarakat sekitar kawasan penyangga telah membuat mereka terpaksa melakukannya.

\section{Jumlah dan Kepadatan Penduduk.}

Penduduk di desa kajian merupakan campuran dari suku Jawa dan Madura, seperti di Desa Curahnongko (60\%) penduduknya adalah suku Madura umumnya bukan suku Madura yang disebut yang disebut pendalungan, melainkan sudah merupakan campuran antara suku Jawa dan Madura. Berbeda dengan masyarakat yang berasal dari Desa Sanenrejo dan Desa Wonoasri tampak dominan suku Jawa $(80 \%)$. Secara rinci jumlah penduduk dan penyebarannya dapat dilihat pada Tabel 4 .

Jumlah penduduk desa di lokasi kajian berdasarkan tabel diatas berjumlah 24.745 jiwa, terdiri atas 12.343 ( 49,9\%) jiwa laki-laki dan 12.402 (50,1\%) jiwa perempuan. Rata-rata tiap keluarga terdiri dari 4 jiwa. Ini berarti bahwa di Desa Sanenrejo mempunyai jumlah penduduk paling banyak, yang memungkinkan mempunyai sumber daya manusia paling tinggi.

\section{Tingkat Pendidikan}

Dari Aspek Pendidikan, sebagian masyarakat di sekitar TN MB berpendidikan Sekolah Dasar (60,69\%) berturut turut diikuti SLTP (21,58\%) SLTA (6,77\%) dan Sarjana $(0,96 \%)$ seperti ditun-jukan dalam Tabel 5. Dari data tersebut menunjukkan bahwa masih sangat banyat banyak penduduk yang memiliki pendidikan rendah. Fasilitas penyelenggaraan pendidikan pada

Tabel 4 : Jumlah Penduduk, Sex Ratio, Jumlah KK dan Rata-Rata Keluarga

\begin{tabular}{|c|l|c|c|c|c|c|c|}
\hline \multirow{2}{*}{ No } & Desa/Village & \multicolumn{2}{|c|}{$\begin{array}{c}\text { Jenis Kelamin } \\
\text { (Gender) }\end{array}$} & \begin{tabular}{c} 
Jumlah \\
Jiwa \\
\cline { 3 - 4 } (Sumupsoul)
\end{tabular} & $\begin{array}{c}\text { Sex } \\
\text { Ratio }\end{array}$ & $\begin{array}{c}\text { Jml KK } \\
\text { (Sum up } \\
\text { KK) }\end{array}$ & $\begin{array}{c}\text { Rata-rata } \\
\text { tiap Kel } \\
\text { (Mean every } \\
\text { family) }\end{array}$ \\
\hline 1 & Andongrejo & 2666 & 2831 & 5.497 & 94,17 & 1.354 & 4 \\
\hline 2 & Curahnongko & 2883 & 2833 & 5.716 & 101,76 & 1.716 & 3 \\
\hline 3 & Sanenrejo & 2881 & 2978 & 5.859 & 96,74 & 1.498 & 4 \\
\hline 4 & Wonoasri & 3913 & 3760 & 7.673 & 104.07 & 2.558 & 3 \\
\hline
\end{tabular}

Sumber data : Monografi Desa Andongrejo, desa Curahnongko, desa Sanenrejo dan desa Wonoasri, semester 1Tahun 2002 
Tabel 5. Tingkat Pendidikan Masyarakat Desa Daerah Penyangga

\begin{tabular}{|c|l|c|c|c|c|}
\hline \multirow{2}{*}{$\begin{array}{c}\text { Nomor } \\
\text { (Number) }\end{array}$} & \multirow{2}{*}{$\begin{array}{c}\text { Desa } \\
\text { (Village) }\end{array}$} & \multicolumn{4}{|c|}{ Tingkat Pendidikan (Mount Education) } \\
\cline { 3 - 6 } & SD & SLTP & SLTA & Sarjana \\
\hline 1 & Andongrejo & 2.216 & 230 & 60 & 5 \\
\hline 2 & Curahnongko & 2.314 & 324 & 394 & 41 \\
\hline 3 & Sanenrejo & 1.734 & 289 & 156 & 13 \\
\hline 4 & Wonoasri & 5.377 & 290 & 99 & 5 \\
\hline
\end{tabular}

Sumber data : Monografi Desa Andongrejo, desa Curahnongko, desa Sanenrejo dan desa Wonoasri, semester 1Tahun 2002

lokasi kajian masih sangat terbatas yakni hanya tingkat SLTP, sedangkan untuk menempuh pendidikan yang lebih tinggi masyrakat harus keluar desa yang jaraknya sangat jauh dan biasanya anak-anak yang menempuh pendidikan tingkat SLTP dan SLTA harus kost di dekat sekolahnya. Ini menunjukan bahwa fasisilitas penyelenggaraan pendidikan di lokasi kajian masih sangat kurang, sehingga perlu di dirikan sekolah-sekolah yang lebih tinggi seperti tingkat SLTP dan SLTA di sekitar lokasi penelitian

\section{Jenis Mata Pencaharian}

Jenis mata pencaharian masyarakat di lokasi penelitian sebanyak 9.526 orang (44.3\%),petani, dan 6.753 orang (31.5\%) buruh tani seperti ditunjukan dalam Tabel 6 di atas. Sebagian besar petani adalah petani lahan basah. Disamping petani, mata pencaharian penduduk lainnya adalah swasta 2.467 orang (11.5\%) Lain-lain 972 orang (4,5\%), Pedagang $756(3.5 \%)$ tukang 732 orang $(3.4 \%)$, PNS / ABRI 224 orang $(1.04 \%)$ dan yang paling rendah adalah nelayan hanya 53 orang $(0.25 \%)$ karena yang berprofesi sebagai nelayan terdapat di Desa Andongrejo. Disamping mata pencaharian utama tersebut, masyarakat mulai membudidayakan tanaman emponempon yang bahan bakunya mengambil dari hutan yang selanjutnya dibuat jamu dan

Tabel 6. Jenis Mata Pencaharian di Desa Lokasi kajian

\begin{tabular}{|c|l|c|c|c|c|c|c|c|c|c|}
\hline No & Desa (Village) & $\begin{array}{c}\text { PNS/ } \\
\text { ABRI }\end{array}$ & $\begin{array}{c}\text { Keb/ } \\
\text { Swasta }\end{array}$ & $\begin{array}{c}\text { Peda } \\
\text { Gang } \\
\text { (Merchant) }\end{array}$ & $\begin{array}{c}\text { Petani } \\
\text { (Farmer) }\end{array}$ & $\begin{array}{c}\text { Nela } \\
\text { Yan } \\
\text { (Fisher } \\
\text { Man) }\end{array}$ & $\begin{array}{c}\text { Tukang } \\
\text { (Work- } \\
\text { man) }\end{array}$ & $\begin{array}{c}\text { Buruh } \\
\text { Tani } \\
\text { Farm } \\
\text { Worker) }\end{array}$ & $\begin{array}{c}\text { Lain- } \\
\text { Lain } \\
\text { (Ect) }\end{array}$ & $\begin{array}{c}\text { Jml. } \\
\text { (Total) }\end{array}$ \\
\hline 1 & Andongrejo & 10 & 1.664 & 282 & 1248 & 53 & 310 & 1169 & 13 & 4749 \\
\hline 2 & Curahnongko & 108 & 203 & 52 & 1540 & - & 216 & 1211 & 50 & 3380 \\
\hline 3 & Sanenrejo & 42 & 143 & 308 & 3265 & - & 109 & 1906 & 8 & 5781 \\
\hline 4 & Wonoasri & 64 & 457 & 114 & 3473 & - & 97 & 2467 & 901 & 7573 \\
\hline & JUMLAH & 224 & 2467 & 756 & 9526 & 53 & 732 & 6753 & 972 & 21483 \\
\hline & Rata - rata & 56 & 154.2 & 189 & 2381 & 13 & 183 & 1688 & 243 & 4907,2 \\
\hline & Prosentase & 1.04 & 11,5 & 3.5 & 44.34 & 025 & 3.4 & 31.43 & 4.5 & \\
\hline
\end{tabular}

Sumber data : Monografi Desa Andongrejo, Desa Curahnongko, Desa Sanenrejo dan Desa Wonoasri, semester 1Tahun 2002 
Tabel 7. Rata- Rata Tingkat Pendapatan Penduduk.

\begin{tabular}{|c|l|c|}
\hline No & \multicolumn{1}{|c|}{ Desa } & Rata-rata Pendapatan (Rp/Kapita/Th) \\
\hline 1 & Andongrejo & 803.528 \\
2 & Curahnongko & 1.181 .321 \\
3 & Sanenrejo & 1.000 .061 \\
4 & Wonoasri & 1.597 .066 \\
\hline \multicolumn{2}{|c|}{ Total } & 4.581 .976 \\
\hline
\end{tabular}

Sumber data : Diolah dari data primer

dipasarkan di sekitar desa dan bahkan sudah ke luar desanya.

\section{Tingkat Pendapatan Penduduk}

Pendapatan penduduk di lokasi kajian yang dapat mendukung ekonomi cukup besar adalah dari Kiriman. Banyaknya masyarakat yang bekerja sebagai TKI, juga ibu-ibu PKK yang tergabung dalam TOGA (Tanaman Obat Keluarga) membentuk suatu kelompok pengrajin industri jamu tradisional yang cukup terkenal di sekitar Taman Nasional bahkan sampai di Kabupaten Jember, namun karena kurangnya modal usaha industri jamu yang ada di desa-desa sekitar Taman Nasional tidak berkembang karena belum mempunyai label, karena sulitnya mencari ijin dari Dinas Kesehatan yang menelan biaya per produk Rp.100 juta rupiah. Hal ini yang menjadi hambatan kurang berkembangnya industri jamu di kawasan Taman Nasional. Industri jamu ini dapat memberikan kontribusi terhadap ekonomi keluarga. Data-data pendapatan perjiwa pertahun yang dapat dicapai oleh setiap keluarga dapat dilihat pada pada Tabel 7

Dari Tabel 7 di atas dapat dilihat bahwa pendapatan penduduk di lokasi kajian rata-rata pendapatannya adalah sebesar Rp. 1.145.494.- Keadaan tersebut menunjukkan bahwa terdapat ketimpangan pendapatan antara penduduk. Tingkat pendapatan rata-rata yang relatif tinggi terdapat pada Desa Wonoasri dan Desa Curahnongko, sedangkan pendapatan ratarata yang relatif rendah terdapat pada Desa Andongrejo.

Dengan menggunakan tolok ukur pendapatan keluarga senilai $320 \mathrm{~kg}$ beras per jiwa per tahun (Kasrino, F. 1984) atau senilai Rp.960.000.- maka pendapatan penduduk di desa penelitian dapat dibedakan atas pendapatan tinggi bila pendapatan perkapita pertahun lebih besar dari Rp.960.000.- dan sebaliknya pendapatan perkapita pertahun rendah bila lebih kecil atau sama dengan Rp.960.000.-

Untuk dapat hidup layak yang sesuai dengan harapan pada umumnya petani setempat, menurut hasil wawancara dengan responden maka petani harus memperoleh penghasilan paling sedikit Rp.350.000.- / bulan (Rp.4.200.000.- / tahun). Pendapatan tersebut bila dibasiskan pada lahan, maka petani di lokasi kajian tersebut minimal harus mempunyai lahan seluas 1,2 $\mathrm{Ha}$ meliputi sawah, tegal dan pekarangan. Melihat rata-rata kepemilikan lahan yang masih relatif kecil karena itu masih jauh dari mencukupi untuk dapat hidup dengan layak. Maka peranan pendapat di luar pendapatan yang berbasis lahan sangat menentukan. 
Bila dibandingkan dengan dengan standart hidup layak menurut Sayogyo yaitu ekivalen beras $320 / \mathrm{kg} / \mathrm{kapita}$ per tahun. Dan rata-rata keluarga petani ada 4 orang. Dan harga beras per kg. Rp.2.000.- maka petani paling sedikit harus mempunyai pendapatan pertahun rata-rata Rp.2.560.000.Harapan hidup layak yang diinginkan oleh masyarakat di lokasi kajian masih terlampau tinggi dari pada yang digariskan oleh Sayogyo. Hal ini disebabkan karena harapan yang diinginkan masyarakat sudah meliputi semua pengeluaran untuk kebutuhan hidup.

\section{Keadaan Sosial Ekonomi}

Penduduk daerah penyangga Taman Nasional Meru Betiri mempunyai luas pemilikan lahan sangat sempit, tingkat pendidikan rendah dan tingkat pendapatannya juga rendah. Kondisi sosial ekonomi masyarakat sekitar kawasan Taman Nasional Meru Betiri akan selalu berpengaruh langsung terhadap upaya pelestarian sumberdaya alam.

Kondisi sosial ekonomi masyarakatnya relatif rendah umumnya didukung pula dengan tingkat pendidikan yang rendah, ini menyebabkan kurangnya pengertian dan pengetahuan masyarakat pada upaya perlindungan kawasan konservasi. Dengan demikian peran serta mereka pada upayaupaya konservasi masih sulit diharapkan.

Sedangkan mata pencaharian yang utama di lokasi kajian (80\%) adalah petani dan buruh tani sedangkan sisanya PNS/ ABRI, pedagang, nelayan dan swasta. Sehingga untuk mencukupi kebutuhan masyarakat, maka daerah penyangga Taman Nasional Meru Betiri dijadikan alternatif bagi pemenuhan kebutuhan pokok hidupnya. Kontribusi pengambilan hasil hutan dalam pemenuhan kebutuhan pokok disajikan pada Tabel 8 berikut

Tingkat pemenuhan penduduk terhadap kawasan Taman Nasional Meru Betiri ditunjukkan dengan besar kontribusi pengambilan hasil hutan terhadap pendapatan total keluarga pertahun berdasarkan Tabel 8. Kontribusi pendapatan yang berasal dari pengambilan hasil hutan penduduk daerah penyangga Taman Nasional Meru Betiri rata-rata sebesar Rp. 763.252,5 pertahun atau sebesar 16,80\%. Pendapatan yang tinggi berasal dari hasil hutan tersebut diperoleh bukan dari kegiatan mengambil hasil hutan sendiri, melainkan dari perdagangan hasil hutan.

Tabel 8. Kontribusi Pengambilan Hasil Hutan Dalam Pemenuhan Kebutuhan Pokok

\begin{tabular}{|l|l|l|r|r|}
\hline \multirow{2}{*}{ No } & \multirow{2}{*}{ Desa } & \multicolumn{3}{|c|}{ Pendapatan Keluarga Rata } \\
\cline { 3 - 5 } & & $\begin{array}{c}\text { Pendapatan Total } \\
\text { (Rp/Th) }\end{array}$ & \multicolumn{2}{|c|}{ Pengambilan hasil Hutan } \\
\cline { 3 - 5 } & & 3.272 .500 & 748.500 & Rp/Th \\
\hline 1 & Andongrejo & 5.725 .000 & 130.000 & 2,87 \\
2 & Curahnongko & 3.774 .930 & 874.150 & 23,16 \\
3 & Sanenrejo & 6.876 .860 & 1.300 .360 & 18,91 \\
4 & Wonoasri & 4.912 .3225 & $763.252,5$ & 16,80 \\
\hline & Rata - rata &
\end{tabular}

Sumber data : Diolah dari data primer 


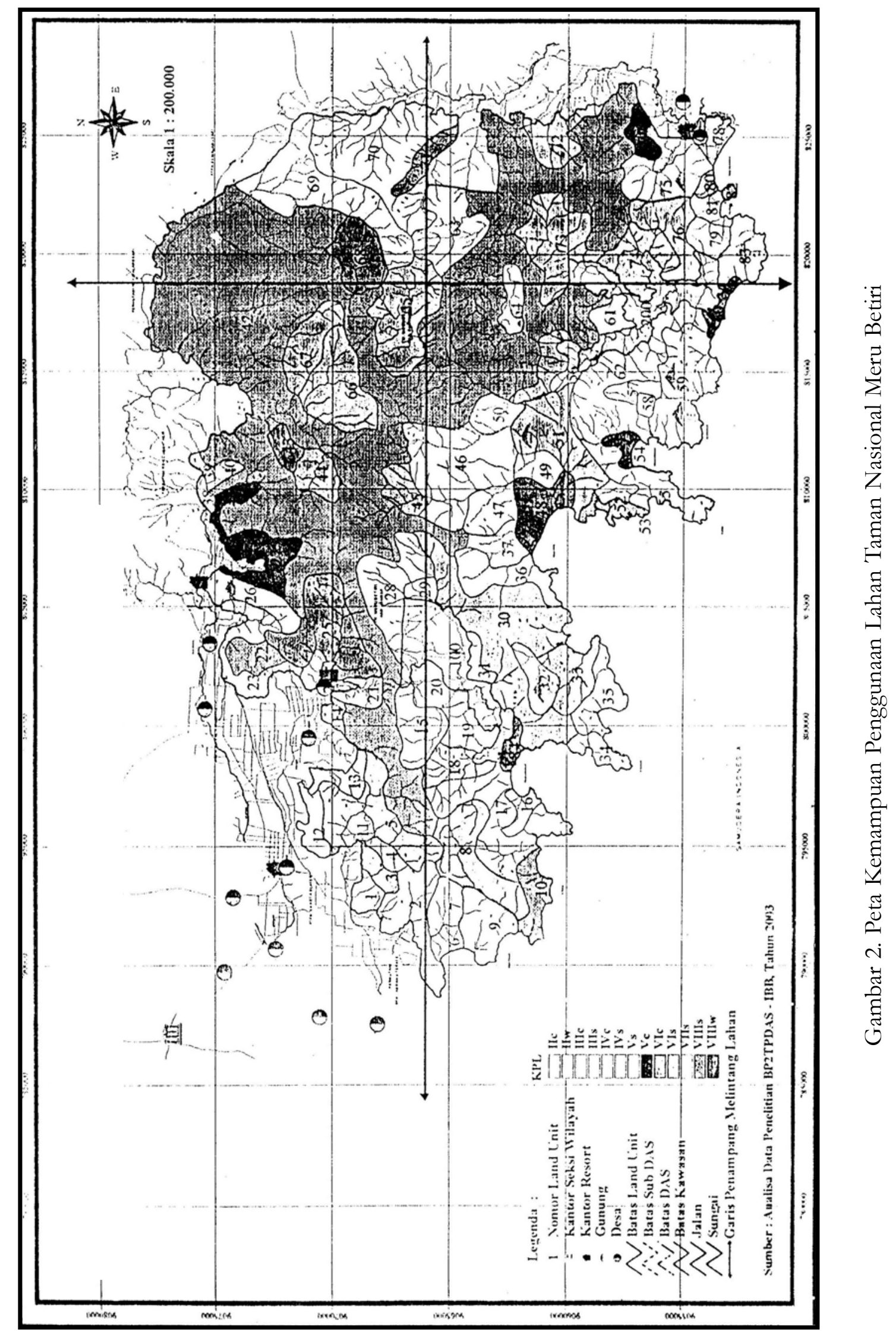




\section{Kegiatan Masyarakat di Taman Nasional}

Pada umumnya masyarakat sekitar kawasan Taman Nasional mempunyai kebiasaan mengambil tumbuhan dan satwa liar yang berada di dalam kawasan Taman Nasional. Kebiasaan masyarakat tersebut jelas melanggar Undang-Undang. Sebagai salah satu upaya untuk mengatasi hal tersebut antara lain perlu memberikan pelatihan pembudidayaan berbagai jenis tumbuhan dan satwa liar yang memberikan nilai ekonomis pada masyarakat di sekitar kawasan Taman Nasional.

Untuk melaksanakan hal tersebut diperlukan kerjasama antara pihak Pengelola Taman Nasional dengan pihak perguruan tinggi serta pihak lain terutama dalam hal dukungan dana dari pemerintah, sehingga dapat bermanfaat bagi masyarakat sekitar Taman Nasional maupun bagi Pengelola Taman Nasional. Kegiatan masyarakat yang semula terbiasa dengan mengambil hasil hutan dari kawasan Taman Nasional dapat beralih profesi. Dengan membuat jamu tradisional, selain dapat memberikan penghasilan tambahan bagi masyarakat sekitar Taman Nasional juga dapat mengubah perilaku, yang semula mengambil hasil hutan dari Taman Nasional menjadi tidak mengambil karena kesibukan membuat jamu. Sehingga volume untuk masuk ke Taman Nasional jadi berkurang. Hal ini dapat mendukung kelestarian Taman Nasional dan dapaat mensejahterkan masyarakat sekitar kawasan Taman Nasional.

\section{Upaya Taman Nasional Terhadap Masyarakat dan Kegiatan Reha- bilitasi}

Upaya Pengelola Taman Nasional Meru Betiri untuk mencapai suatu keberhasilan program Rehabilitasi di kawasan penyangga melalui tahapan-tahapan, seperti sosialisai dengan masyarakat sekitar Taman Nasional dalam membuat aturan-aturan tentang penggunaan lahan di Taman Nasional. Dalam hal ini pihak pengelola Taman Nasional bersama masyarakat dan Lembaga Swadaya Masyarakat sekitar Taman Nasional membuat draf aturan - aturan yang harus disepakati bersama.

Setelah aturan disepakati bersama, disosialisasikan lagi ke masyarakat di kawasan penyangga, masing-masing Kepala Keluarga mendapatkan lahan garapan seluas $0,25 \mathrm{Ha}$, setelah lima tahun wajib mengajukan ijin lagi. Setiap dua tahun diadakan evaluasi terhadap lahan garapan apakah masyarakat telah melakukan seperti pada perjanjian, apabila ada masyarakat yang tidak melakukan rehabilitasi seperti dalam perjanjian akan diberi sangsi bahkan bisa dicabut ijinnya.

Aturan yang wajib dilakukan oleh masyarakat sekitar Taman Nasional antara lain selain mananam tanaman semusim (kacang tanah, kacang panjang, cabe dan singkong), diwajibkan menanam tumbuhan kayu-kayuan (Nangka, Pakem/ kluwak, Pete, Sukun) dll. Kondisi Kawasan penyangga yang telah direhabilitasi oleh masyarakat sekitar kawasan dengan tanaman campuran atau lebih diarahkan ke Agroforestry.

Masyarakat telah melakukan rehabilitasi lahan dengan memperhatikan konservasi tanah walaupun belum sempurna, masyarakat telah membuat teras-teras untuk penanaman tanaman semusimnya. Hal ini terlihat bahwa sudah ada kegiatan rehabilitasi lahan dengan 
menanam berbagai tanaman, seperti tanaman semusim (kacang tanah, singkong, kacang panjang dan cabe), juga tanaman kayu-kayuan seperti (nangka, pakem/ kluwak, pete) Penanaman kayu-kayuan ini adalah untuk memenuhi aturan Taman Nasional dengan catatan boleh mengambil buahnya tetapi dilarang menebang pohonnya, demi tercapainya tujuan program rehabilitasi di Zona Rehabilitasi Taman Nasional Meru Betiri untuk kelestarian hutan dan perbaikan lingkungan dan masyarakat sekitar kawasan Taman Nasional sejahtera.

\section{KESIMPULAN}

1. Taman Nasional Meru Betiri (TNMB) merupakan wilayah yang mempunyai curah hujan rendah (tipe D) pada bentuk lahan pegunungan dan perbukitan, dengan dominasi formasi batuan beku dan jenis tanah sebagian besar Entisol. Kondisi demikian menjadikan aliran sungai di musim kemarau sangat terbatas walaupun daerah tangkapan airnya tertutup oleh hutan alam rapat.

2. Tekanan atau ancaman penduduk sekitar Taman Nasional Meru Betiri (TNMB) cukup tinggi ini terbukti oleh mata pencaharian masyarakat yang umumnya 9.526 orang (44.3\%),petani, dan 6.753 orang $(31.5 \%)$ buruh tani. Kepadatan Agraris mencapai 16,6 jiwa/Ha. Dan rata-rata kepemilikan lahan $0,219 \mathrm{Ha} / \mathrm{KK}$ dan usia produktif mencapai 63,8\%. Perlunya mencari pendapatan di luar hutan, misalnya pemerintah menggalakkan di sektor Pariwisata dan

3. Masih sedikitnya pendidikan Tingkat SLTP ( 21,58\%) dan SLTA (6,77\%) di lokasi penelitian juga merupakan ancaman bagi TNMB. Tingkat Pendidikan SD masih mendominasi di lokasi penelitian sehingga sangat perlu bagi pemerintah untuk mendirikan sekolah-sekolah di tingkat SLTP dan SLTA

4. Faktor sosial dan ekonomi masyarakat di kawasan Taman Nasional Meru Betiri masih tergolong rendah, hal ini terlihat dari besarnya pendapatan dari lahan pertanian dan di luar pertanian. akan tergantung pada besar kontribusi pengambilan hasil hutan terhadap pendapatan keluarga. Kontribusi pendapatan yang berasal dari pengambilan hasil hutan penduduk daerah penyangga Taman $\mathrm{Na}$ sional Meru Betiri rata-rata sebesar Rp. 763.252,50- pertahun atau sebesar $16.80 \%$. Pendapatan yang tinggi berasal dari hasil hutan tersebut diperoleh bukan dari kegiatan mengambil hasil hutan, melainkan dari perdagangan hasil hutan.

5. Dengan memperhatikan kondisi sosial ekonomi masyarakat di kawasan penyangga, maka kegiatan rehablitasi dengan pengembangan sosial forestry akan sangat tepat. 


\section{DAFTAR PUSTAKA}

Alikodra, HS. 1976. Dasar- dasar Pengelolaan Kawasan Konservasi. FakultasnKahutanan Institut Pertanian Bogor, Bogor.

Balai Pengelolaan Daerah Aliran Sungasi Sampean - Madura , 2002. Laporan Hasil Inventarisasi Lokasi dan Sosekbud Masyarakat Sekitar Taman Nasional Meru Betiri. Bondowoso, Jawa Timur.

Devung G.S. 1996. Praktik dan Pranata Tradisional Pemanfaatan dan Pengelolaan Sumber Daya Hutan oleh Masyarakat Kenyah di Wilayah Hulu Sungai Bahau, Kalimantan Timur. Magister Thesis. Program Pasca Sarjana Universitas Indonesia. Jakarta.

Desa Andongrejo,2002. Monografi Desa Andongrejo, Kecamatan Tempurejo Tabun 2002, Semester I

Desa Curahnongko,2002. Monografi Desa Curabnongko, Kecamatan Tempurejo Tabun 2002, Semester I

Desa Sanenrejo,2002. Monografi Desa Sanenrejo, Kecamatan Tempurejo Tabun 2002, Semester I

Desa Wonoasri,2002. Monografi Desa Wonoasrti, Kecamatan Tempurejo Tabun 2002, Semester I

Goldsmith, J. 1995. Perangkap Yayasan Obor Indonesia Jakarta.

Kartodihardjo,H. 1998. Peningkatan Kinerja Pengusahaan Hutan Alam Melalui kebijaksanaan Penataan Institusi . Program Pasca Sarjana Institut Pertanian Bogor. Bogor

Kasrino F, 1984. Prospek Pembangunan Ekonomi Pedesaan Indonesia, Yayasan Obor, Jakarta

Paimin, Dkk, 2003. Kajian Kriteria dan Indikator Penetapan ZonasiTaman Nasional Meru BetiriJember, Jawa Timur. Hasil Penelitian BP2TP DAS -IBB Surakarta

Scott, R. Institution and Organization. Sage Publication : An International Educational and Professional Publiser. Thousand Oaks, London - New Delhi.

Wardoyo, W, 2001, Strategi Pengelolaan Konservasi Dalam Rangka meningkatkan Pembangunan Daerah, Dalam Sudarmadji, 2001 Konservasi Sumber Daya Alam, Jember 1 - 22 